\title{
A Framework for Managing Building Waste from the Restoration of Historic Cairo
}

\author{
Sameha Ibrahim Salem*, Yasmine Sabry Hegazi, Sherif Kamal Dessouky \\ Architectural Department, Zagazig University, Egypt
}

Received August 18, 2021; Revised November 1, 2021; Accepted November 21, 2021

\begin{abstract}
Cite This Paper in the following Citation Styles
(a): [1] Sameha Ibrahim Salem, Yasmine Sabry Hegazi, Sherif Kamal Dessouky, "A Framework for Managing Building Waste from the Restoration of Historic Cairo," Civil Engineering and Architecture, Vol. 9, No. 7, pp. 2362 - 2380, 2021. DOI: 10.13189/cea.2021.090723.
\end{abstract}

(b): Sameha Ibrahim Salem, Yasmine Sabry Hegazi, Sherif Kamal Dessouky (2021). A Framework for Managing Building Waste from the Restoration of Historic Cairo. Civil Engineering and Architecture, 9(7), 2362 - 2380. DOI: 10.13189/cea.2021.090723.

Copyright $\odot 2021$ by authors, all rights reserved. Authors agree that this article remains permanently open access under the terms of the Creative Commons Attribution License 4.0 International License

\begin{abstract}
The purpose of this paper is to develop a framework for managing wastes resulting from the restoration works in historic Cairo, Egypt. To achieve the above mentioned aim, a research methodology was designed to accomplish four objectives. Firstly, a literature review was used to investigate the nature of historic buildings, and national and international experiences of managing restoration waste. Secondly, 43 case studies from historic Cairo were used to identify the most common practices for managing building restoration waste. Thirdly, a survey questionnaire was conducted with experts to evaluate the most sustainable indicators of assessing building material waste. Finally, a framework was developed to facilitate the management of buildings' restoration waste in historic Cairo. Moreover, it concludes the most important factors of buildings' materials waste management in historic Cairo. The research discusses the importance of historic buildings and their status of ignorance and obsoleteness. In addition, it highlights the deficiencies of the waste management system. Furthermore, it presents a framework to manage waste resulting from restoration work on the buildings of historic Cairo, which represents a synthesis that is novel and creative in thought and adds value to the knowledge in a new way.
\end{abstract}

Keywords Waste Management, Framework, Conservation Projects, Historic Cairo

\section{Introduction}

Achieving sustainable development goals necessitates striking a balance between the community's social, environmental, and economic needs and available resources. The main vision of a sustainable built future is to create innovative designs that make efficient use of energy and smart materials. This vision should consider historic building centuries ago [1]. Historic structures should be preserved for future generations because they connect communities to their history. Many cultural and historic buildings are being renovated, adapted, and reused rather than demolished to revitalize and generate sustainable values for these structures [1-5]. According to recent statistics, the building and construction sector is one of the most resource-intensive industries, beginning with the extraction of raw materials and continuing through manufacturing, transportation, and waste disposal [6]. Sowjanya [7] estimates that a large amount of waste that ends up in landfills causes environmental problems. Site managers are not always concerned with properly managing generated waste [6]. Waste management systems fail for a variety of reasons, including poor coordination [8], a lack of genuine stakeholder involvement in the planning processes, a lack of understanding of the system components, and external factors influencing managerial performance in relation to the waste management concept [9].

Waste management in Egypt lacks reliable data and precise quantitative estimates, which could result in 
significant economic deficiencies in the long run. This could be attributed to a lack of funding and a scarcity of trained personnel in waste management activities such as sorting and handling waste, as well as a complete lack of technical means to ensure the waste life cycle is followed and the production of reusable or recycled materials is verified. Relatively, it appears that conservation projects that adhere to international charters and conventions may be familiar with this concept, as it was presented in Nara Document of Authenticity, which ensures the use of original materials in the restoration of historic buildings. Historic Cairo's waste management needs to be more structured and subject to a highly sustainable management framework to conserve these unique non-renewable resources. As a result, the purpose of this paper is to create a framework for managing historic Cairo's building restoration waste.

\section{Literature Review}

\subsection{Historic Buildings}

A historic site is an official location where pieces of political, military, cultural, or social history have been preserved for their worth. Historic buildings are typically protected by law, and many have been designated as official national historic sites. They may be graded based on their merit as follows [10]:

- Grade 1: Buildings of outstanding merit: need every effort to be preserved if possible.

- Grade 2: Buildings of special merit: need efforts to selectively preserve them.

- Grade 3: Buildings of some merit: if preservation is not practicable, it would be preferred to preserve them in some form and alternative means could be considered.

Historic buildings are an important part of every country's heritage wealth. Historic buildings belong to everyone on the planet, regardless of where they are located. Many of these buildings are still standing in a stable state due to their structure and nature [1]. Their survival necessitates the preservation of the spirit of place, local culture, and physical characteristics [11]. Most historic buildings may have thick walls, multiple layers of wooden flooring and ceilings, and other traditional insulation materials that mean their already keep the building's thermal performance is better than that of concrete buildings [12]. However, they are being ignored and rendered obsolete, which is undermining public perception of their values [1].

\subsection{Early Successful Experience of Managing Restoration Waste}

\subsubsection{Case Study (1): Kolkata Town Hall, Kolkata, India}

Kolkata town hall was built in 1813 in Kolkata city in India, in the central business district (CBD). The building is surrounded by many public administrative and commercial buildings and it was designed in the Palladian-Doric Roman style, which reflects the physical and functional city then [13]. After Independence, the town hall Building was largely neglected and many of its rich components such as marble statues and paintings were shifted to memorial halls and municipal office buildings. In 1998 due to the timely intervention of the Archaeological Survey of India (ASI) and the Calcutta High Court this heritage building was saved from further damage and destruction. It was later renovated to its former glory, and is now used for public gatherings and functions.

Adaptive reuse of this building went through several phases, including documentation, testing, repairing different elements, relegating restoration funds, and managing the process. It currently comprises the first high-tech story-telling museum, "Kolkata Panorama", public gathering spaces, administrative area, academic seminars area and socio-cultural events area [13]. This project provided a new experience to the Indian government and highlighted the benefit of adaptive reuse to help protect heritage buildings and facilitate their preservation process. This approach proved to be a successful alternative to the previous practice of demolishing unused heritage buildings, which helps in preserving these buildings' values to their place and community (see Figure $1 \& 2$ ). 

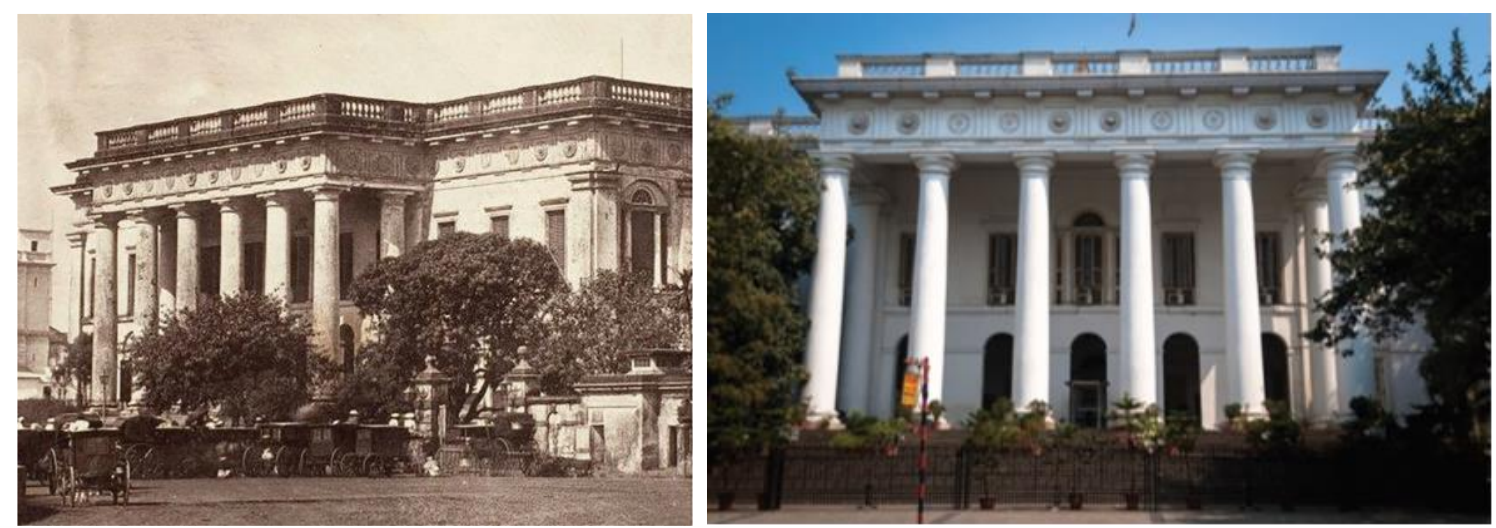

Figure 1. Kolkata Town Hall before and after restoration [14]
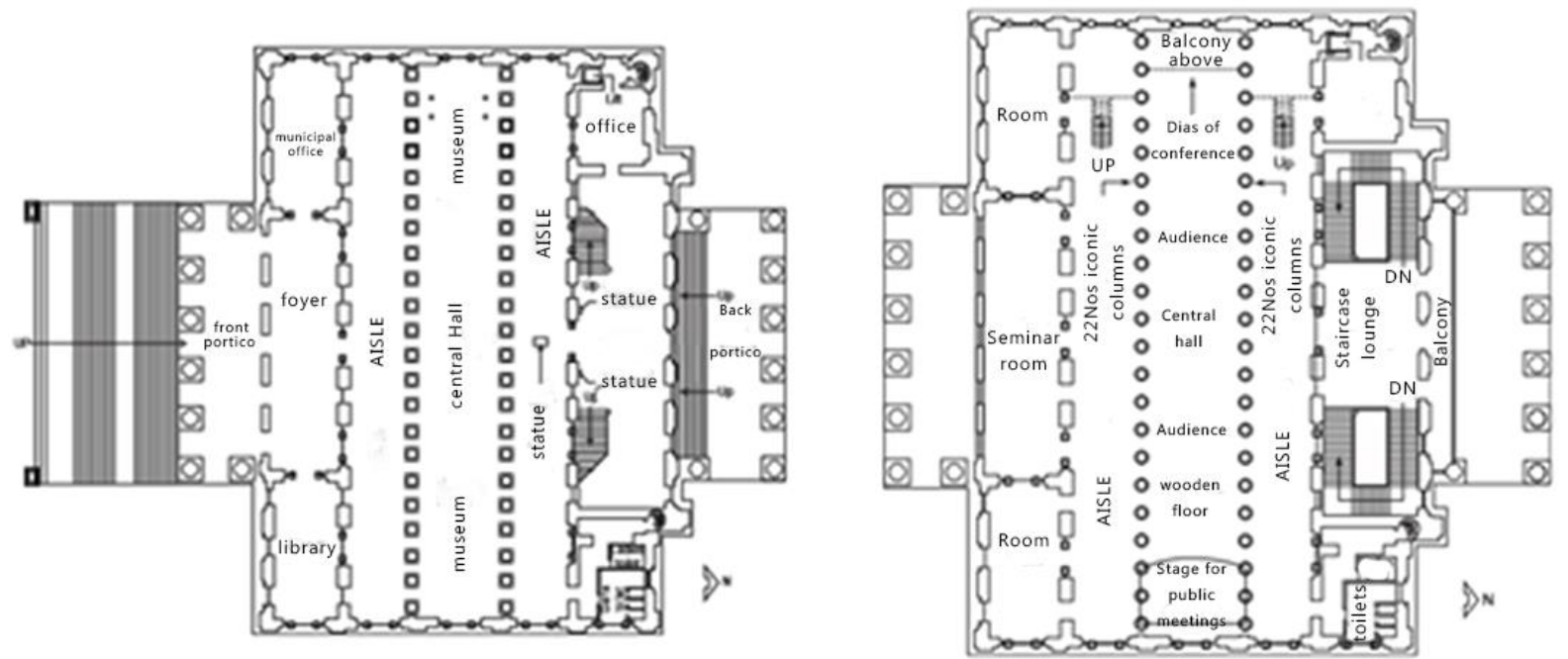

Figure 2. Ground and first floors after restoration [14]

\subsubsection{Case Study (2): The Omani-French Museum, Muscat, Oman}

The Omani-French Museum is an example of adaptive reuse of a heritage building in Oman, which is similar to Egypt. It is also very rich in heritage but lacks the necessary resources to conserve such buildings. It was built between 1820 and 1840 . It was initially dedicated in traditional Omani architecture, with influences from pre-Islamic architecture, symbolizing the friendship between France and Oman (see figure $3 \& 4$ ). It was adapted to document all historical relationships between France and Oman for their conservation. However, some issues arose in its adaptive reuse process, which included: miscommunication between conservation team members, professionals' lack of knowledge to handle the restoration process, limited response to sustainability agenda, inaccuracy of information that resulted in the unnecessary addition of inappropriate building materials and the lack of proper planning policy, legislation, and decision-making. Concerning the building function, esthetics and safety performance, those aforesaid problems resulted in real threats and required an additional re-upgrading process. Restoration works highlighted the importance of involving an integrated team of highly qualified professionals and of using original materials and modern techniques concerning mainly the original environment. That helped to present this unique building in its full authenticity within the context of cultural tourism, to ensure the continuity between past and future [15]. 


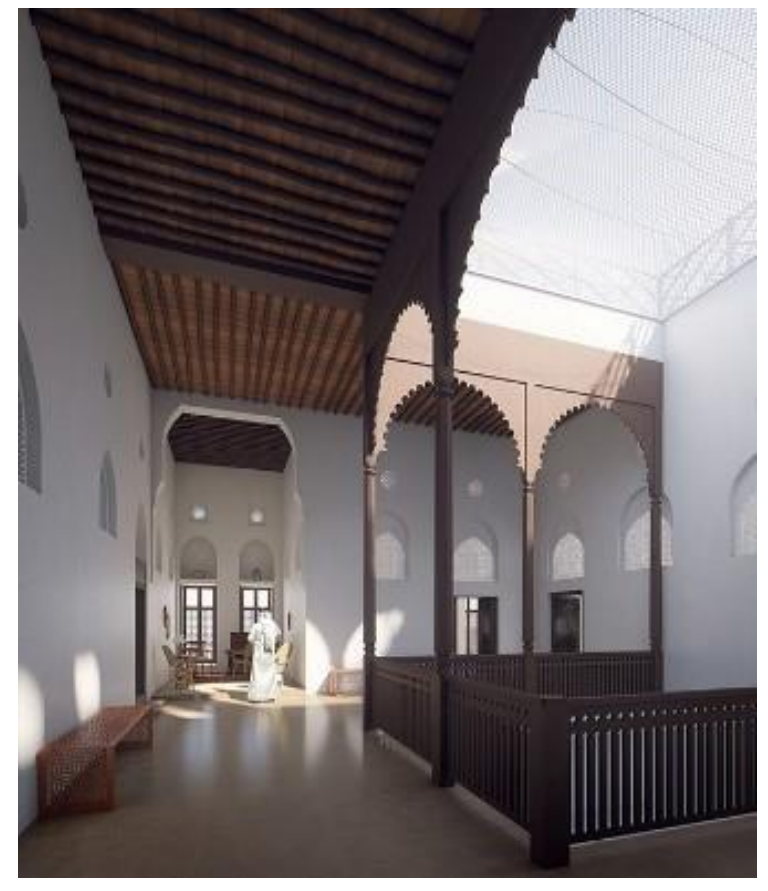

Figure 3. View of inner patio in the Omani-French Museum [16]

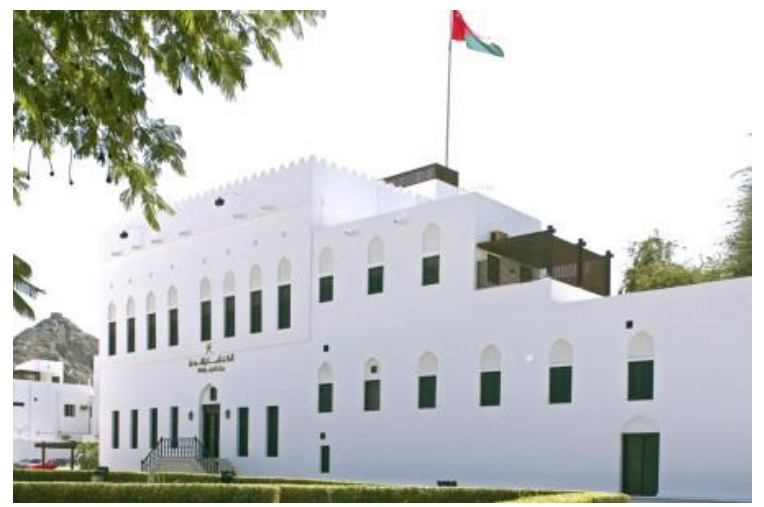

Figure 4. Exterior façade of the Omani-French Museum, showing Omani vernacular architecture [17]

\subsection{Egypt's Experience of Managing Restoration Waste}

Cairo is home to several historical districts and significant monuments that demonstrate the architectural wealth of the city as a wonder of the human urban experience. It was inscribed on the World Heritage List in 1979, recognizing its absolutely unquestionable historical, archaeological, and urbanistic importance. However, Cairo suffered from accumulated problems including: socio-economic pressures, illegal occupations, poor infrastructure, and traffic and transportation issues (see figure $5 \& 6$ ). Toward resolving these problems, UNESCO and the World Heritage Centre (WHC), in cooperation with the Egyptian government, international institutions, and experts, carried out regular missions to evaluate the state of conservation at the site and to strengthen coordination among the institutions involved in its protection, while considering the special character and complexity of historic Cairo [18].

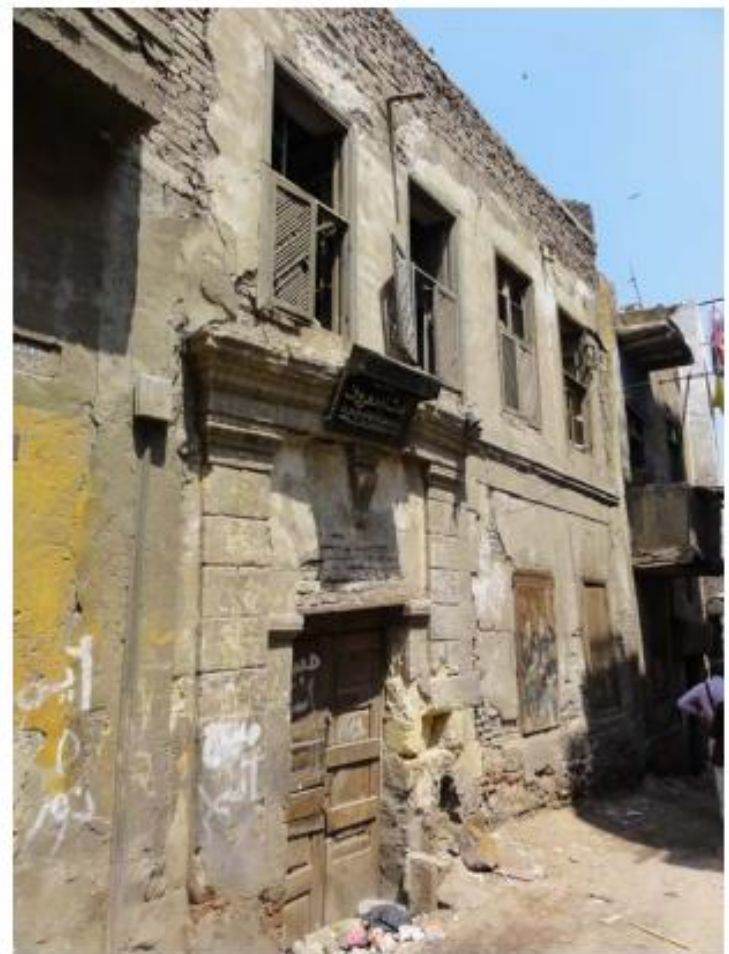

Figure 5. Poor condition of historic buildings, Darb el Labana, Khalifa (by author)

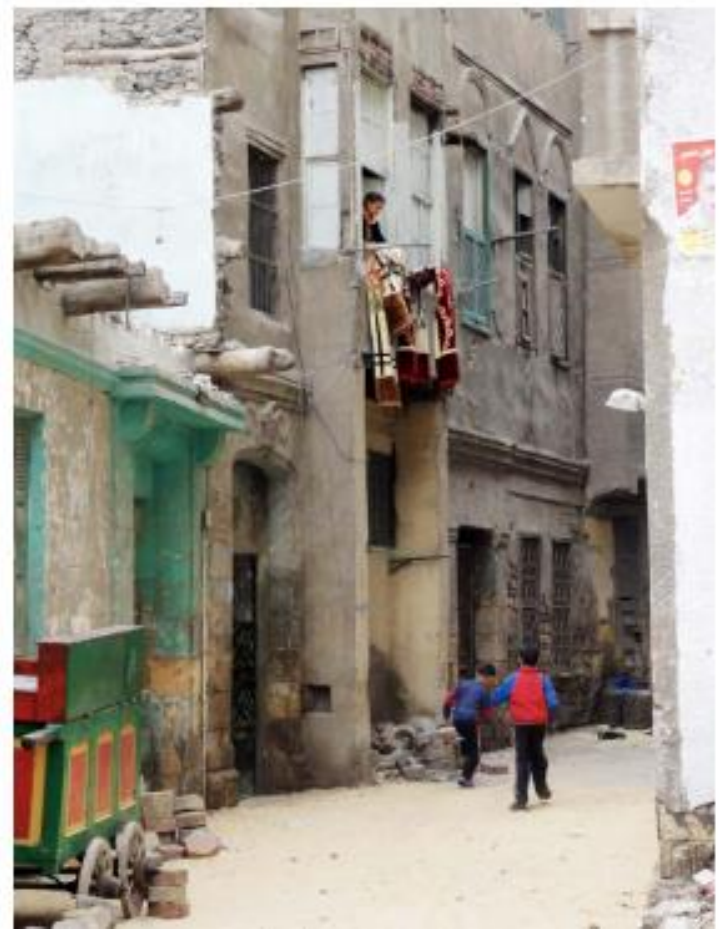

Figure 6. Illegal occupants of historic buildings, Darb el Hosr, Khalifa (by author)

Historic Cairo is considered as a model for a residential city in which all functions are integrated. It represented the interaction of the community with the surrounding 
environment during successive periods that formed its architectural heritage and contributed to the production of its unique personality; consequently, becoming one of the oldest living heritage cities [19].

In $1307 \mathrm{AD}$, Cairo was hit by an earthquake that destroyed most of its buildings and which was considered a warning alarm, alerting people to the need to intervene to preserve, restore and document what was left of its historic buildings. One of the most prominent efforts was that of the scientific expedition accompanying the French campaign (1798-1801 AD), until the Committee for the Preservation of Arab Monuments in Egypt (1881-1961 $\mathrm{AD}$ ) took over the mission of preservation as the first organized, methodical and documented effort to pay attention to the Egyptian cultural heritage. At the end of that stage, many historic buildings faced deterioration and damage due to the poor coordination and conflict of opinion between the authorities concerned with the preservation process.

According to [20], which documented the restoration works of 174 monuments of historic Cairo, there is no clear framework for waste management in the restoration works of historic buildings in Egypt. Management plans are mainly redirected to manage waste in new building construction. The Ministry of Tourism and Antiquities adopted a strategy that integrates the in-depth Egyptian studies in the field of restoration and the foreign expertise to preserve this unique cultural heritage and to highlight the value and richness of the historic Cairo conservation project [21]. Despite the governmental support, the responsibility for heritage management is prioritized to the community to which it belongs and it is a must to adhere to the principles and responsibilities imposed by international conventions [22]. The Nara Document on Authenticity is a document that addresses the necessity of a broader understanding of cultural diversity and cultural heritage about conservation in order to evaluate the value and authenticity of cultural property more objectively [23].

\subsection{Historic Cairo Conservation Project}

The historic Cairo conservation project was divided into two phases: the documentation and studies phase, including inventory of antiquities, assessment of their condition and classification of work priorities; then, the implementation phase, which included conservation and maintenance work such as: the conservation of destroyed parts of buildings, the addition of details and architectural deficiencies, the removal of encroachments inside and outside buildings, taking into account the architectural surroundings in all their dimensions, and, finally, documenting those efforts through printed and published documents [24]. The Ministry of Antiquities' executive program for the historic Cairo conservation project was based on three axes: the priority of preventing risk to archaeological buildings, dividing the work among them according to their needs, and working with an integrated conservation idea that includes historical Cairo as a whole, not limited to protecting one monument [21], Hence, determining the most appropriate way to deal with historic buildings depends on the factors of damage affecting them, to establish the amount of necessary intervention that requires field experts' opinions to be sought [25].

Building material waste management in heritage sites in general, and at historic Cairo as a specific model is subject to the requirements of heritage site management. Comprehensively it could be allowed to reform them and restore the missing parts of them to their previous status for functional reasons, after full documentation which guarantees not to affect the authenticity and originality according to the Nara Document of Authenticity.

\subsection{Revision of the Integrated Sustainable Waste Management}

The development of an integrated sustainable waste management system has been discussed in several publications. Diaz L.F., Savage G.M., Golueke C.G., [26] argued for a holistic approach to an integrated and sustainable solid waste management (SWM) addressing all three dimensions of sustainability (environmental, social, and economic).

Consequently, the characteristic of integrated waste management, being open to all the actors or stakeholders, seems to have been explicitly taken up primarily in the context of developing countries [27]. In the early 1990s, many international nongovernmental organizations (NGOs) became disenchanted with the failure of the conventional, exclusively technical, approach [28]. UNDP, UN-Habitat, and the World Bank set up a collaborative program on municipal solid waste management in developing countries with funding from the Swiss Agency for Development and Cooperation. A conceptual framework for integrated municipal SWM in low-income countries was developed in a workshop convened in Ittingen, Switzerland, in 1995. The framework created a link between the scope, actors, and strategic aspects within the political, socio-cultural, economic, and environmental contexts. This approach is essentially built upon comprehensive notion of sustainability on multiple levels [29].

Anschütz J., IJgosse J., Scheinberg A., [30] developed an integrated waste management model. The resulting model for developing countries recommends the combination of three dimensions when improving a waste management system and it is the same model used within the National Solid Waste Management program in Egypt issued by the Ministry of Environment in accordance with the latest decisions of the Prime Minister in this regard in 2020. The three main dimensions are (1) stakeholders, (2) waste system elements, and (3) system aspects (see Figure 7). 


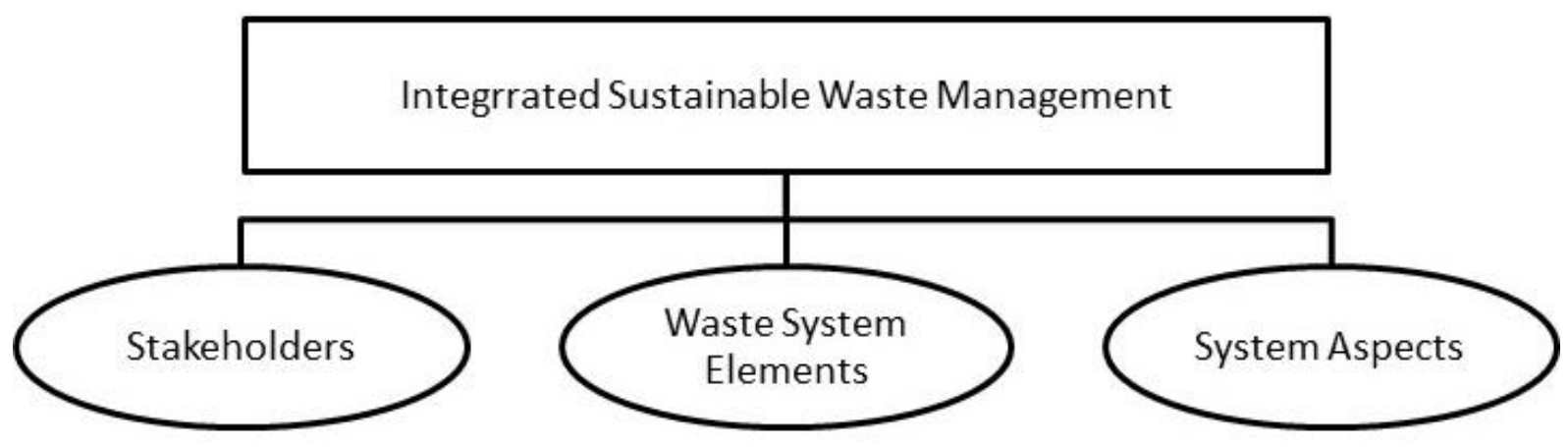

Figure 7. The Integrated Sustainable Waste Management Model [30]

\subsubsection{Stakeholders}

Stakeholders are defined as those to whom one or more of the following characteristics apply: those who have exposed losses or potential damages due to waste (such as the community with its current residents and future generations), or who have the authority to make positive or negative decisions about waste management (such as various governmental or non-governmental legal and advisors), or who highly rely on waste management decisions (such as the industry that produces materials or services related to construction and demolition work) [31]. According to [11] community participation is one of the most important types of participation in the decision-making process that contributes to proposing the most appropriate strategy for the historic buildings. On the other hand, interviews should be conducted with experts to develop management plans that properly define the needs and expectations of the market vendors, local community, and tourists, taking into account all aspects of sustainability. The key issue seems to be establishing wider corporate responsibility [32], thus, a good coordination among all those who are involved in the construction process is greatly needed to avoid the generation of more waste that requires final disposal [33, 34].

\subsubsection{Waste Management System Elements}

Construction and demolition waste management is the practice of dealing with the waste generated at the end of the material life cycle. It involves managing the activities associated with production, storage, and collection, as well as reuse, recycling, and final disposal in an environmentally compatible manner, with the principles of economy, beauty, and energy conservation [35]. The process of sorting and separating waste is considered one of the most important requirements that precede waste management and contribute to its success and support its sustainability [36]. Unlike other industries, construction and demolition work produces its waste within a specific time during different stages of project progress [37], and it is easier to deal with it at the same stage of waste production than in later stages, so that the sorted materials would be clean and suitable for inclusion in the production of new building materials [38]. There are two types of sorting namely, on-site and off-site sorting [39]. On-site sorting maximizes reuse and recycling and minimizes waste transport and disposal costs [40]. The success of the on-site sorting depends on trained labor availability [41, 42], good management, space available at the site, and the possibilities for sorting construction waste [39]. Off-site sorting is preferable in the case of sorting hazardous waste or the lack of space allocated on-site [43].

Reuse includes preserving materials and reusing them for the same function with the least processing and energy consumption $[44,45]$. To activate the reuse of materials, it is possible to store the remaining materials to facilitate their reuse in other projects in the future or renovation works on the same site [46], or to develop markets for them [42]. Hence, recycling material waste is accomplished in one of two ways: (1) inserting waste as raw materials to produce new ones, or (2) treating and maintaining waste so that it qualifies to be reused for a new life cycle that may differ from the previous one $[41,47,48]$. Finally, material waste is disposed of if it cannot be reused or recycled [49]; however, its volume makes it more difficult to get rid of easily [50].

\subsubsection{System Aspects}

Considerations for activating a sustainable waste management system refer to the aspects that must be taken into consideration to achieve a sustainability system, and it differs from one country to another; where construction waste management requires clear legislation and standardized principles for resource management that include collection, separation, transportation and disposal practices that are applied with the participation of stakeholders [51]. Environmental considerations indicate whether waste management options are preserving the environment and public health [31], provided that materials are not handled according to the principle of absolute proportionality. If the recycled material is compared to a newly produced one, the first judgment will be that the recycled material is more sustainable and less 
harmful to the environment, but it is not a fixed rule, as the recycled product may harm the environment. Hence, it is important to monitor the indicators and continue developing them for a higher quality product from a sustainable environmental perspective [32].

The economic considerations are related to the construction and demolition waste management system with the inputs and outputs of the system. The system begins with the processes of sorting and separating waste to determine the method of dealing with it, even recycling to produce new materials or disposal [52]. The performance of methods dealing with waste shall be economically evaluated through calculating the costs of energy consumption of machines, tools, and transportation, and by studying market prices for both recycled and newly produced materials to compare manufacturing and transportation costs and their returns [32, 53]. Consequently, to obtain the sustainability of the construction and demolition waste management system, the main technical requirements and reliable data available should be provided [54] by which the recycled materials' processes can have an efficiency equal to the new materials in their specifications, or less than them if they can be accepted by the consumer and the available market [38].

\section{Research Design and Methods}

This research adopted the applied approach to achieve its aim and objectives based on action research which can be defined to reduce the gap between theory and practice [55]. Firstly, the research surveyed literature to identify integrated sustainable waste management. Then, quantitative and qualitative techniques were used for data collection and analysis. Data collection is a principal activity in the research process. Data were collected using different methods to achieve certain objectives. This is known as "triangulation," which increases the reliability and validity by verifying data findings from one source with other sources. This strategy reduces the risk and bias associated with using specific methods [56]. The documented data about managing restoration works' waste were not enough to answer all the questions to develop an efficient framework for the current practices used for building restoration waste in historic Cairo; thus, the research conducted a survey questionnaire with a representative sample of experts and project managers in historic Cairo conservation projects to obtain useful, accurate, and scientific answers to fill the gap of documented data about the waste management plan for historic building materials.

The research methodology consisted of a literature review, case studies, and survey questionnaire, and was designed to achieve four objectives (see Figure 8).

- Firstly, to investigate the nature of historic buildings, early successful experiences of managing restoration waste, and Egypt's experience and practices of waste management in historic Cairo. This object was accomplished through a literature review based on textbooks, academic and peer-reviewed journals, conference and seminar proceedings, dissertations and theses, organizations' and government publications, and the internet and related websites.

- Secondly, to investigate the most common practices of building restoration waste applied in historic case studies. This objective was accomplished through the analysis of 43 cases studies in historic Cairo.

- Thirdly, to evaluate the most sustainable indicators of assessing building material waste management system in historic Cairo. This was done through a survey questionnaire with a representative sample of consultants and project managers who are responsible for the project's conservation work.

- Finally, to develop a framework that facilitates the management of buildings' restoration waste in historic Cairo. 


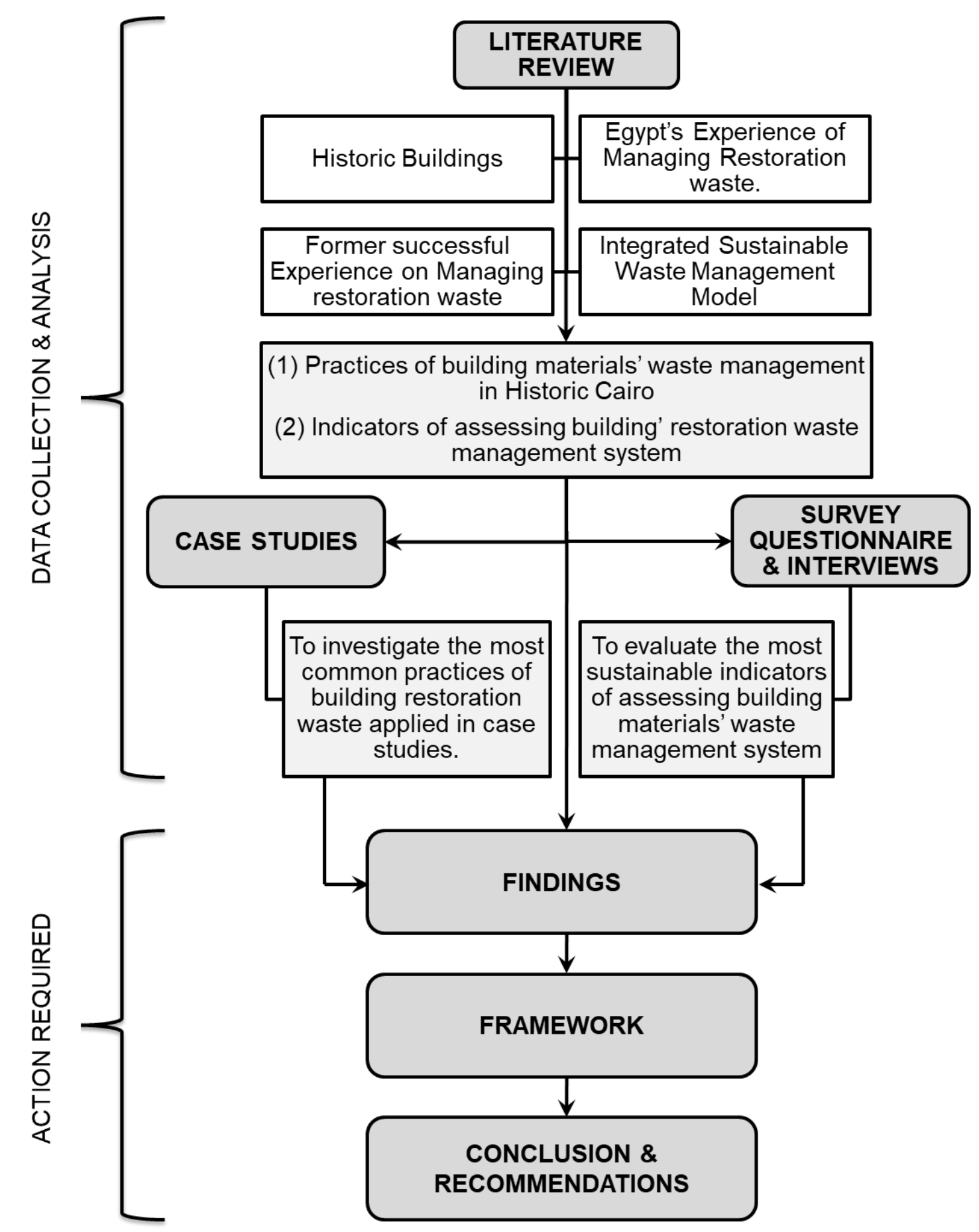

Figure 8. Research Methodology

\subsection{Data Collection Methods}

The proposed framework was tested on 43 case studies of historic Cairo buildings which were visited successively by the authors. Selected case studies were the monuments that had witnessed good attempts at sustainable waste management of their restoration works, even if they had not been completed, and that were clearly documented by the Supreme council of antiquities at their published book [20]. The research materials included a questionnaire consisting of 21 questions that were answered during the visits, while some were answered electronically by those who were not able to answer during the visits. Despite the robust research methods adopted, the COVID-19 pandemic limited face-to-face interaction with respondents, resulting in the authors sending the survey questionnaire in electronic format to respondents. 
The questionnaire addressed a purposive sample of experts in the monuments sector and who were still practicing the profession, to ensure a complete sample. It was divided into three sections. The first part consisted of five questions that measured the stakeholders' participation; the second part, which ranged from questions 6 to 15 , discussed sorting building material waste, the space allocated for sorting, material sorting method, trainee workers for sorting waste, plans for recycling, matching recycled materials to standard specifications before they are used, which materials are reused or recycled, and how to dispose of material waste that cannot be reused or recycled. Finally, the third part contained six questions that discussed safety restrictions, environmental impact of the recycled materials, tracking the sustainability of waste-handling strategies, and stakeholders' care about public safety rules, and providing a good work environment for the workers, and so on. Consequently, the questions could be classified into three categories, as listed in Table 2. The analysis of the questionnaire results was performed using the Statistical Package for the Social Sciences (SPSS).

\section{Data Analysis}

The purposive sample of experts was chosen based on their involvement and experience in restoration works of historic Cairo buildings based on an interview with the personnel management of the historic Cairo project. Forty-five survey questionnaires were distributed to the experts (consultants and project managers) in charge of the historic Cairo project to investigate the most sustainable indicators of assessing building material waste management systems in the case studies chosen. Only 30 completed and returned forms were received, representing a $66.67 \%$ response rate. Jenkins [57] states that a minimum sample size of 25 is required for regression research, so 30 samples were sufficient to test. Table 1 shows the most common practices used in the waste management of building materials in the Historic Cairo conservation project identified by the Ministry of Tourism and Antiquities (2006), whilst Figure 9 refers to the names and locations of the case studies chosen. 
Table 1. Most common practices in building materials' waste management - Historic Cairo conservation project (Developed by the Authors)

\begin{tabular}{|c|c|c|c|c|c|c|c|c|c|c|c|c|c|c|c|c|c|c|c|c|c|c|c|c|c|c|c|c|c|c|c|c|c|c|c|c|c|c|c|c|c|c|c|}
\hline Common practices of restoration & 1 & 2 & 3 & 4 & 5 & 6 & 7 & 8 & 9 & 10 & 11 & 12 & 13 & 14 & 15 & 16 & 17 & 18 & 19 & 20 & 21 & 22 & 23 & 24 & 25 & 26 & 27 & 28 & 29 & 30 & 31 & 32 & 33 & 34 & 35 & 36 & 37 & 38 & 39 & 40 & 41 & 42 & 43 \\
\hline Repair and replacement of stones & $\bullet$ & & - & & & & $\bullet$ & - & & & - & & & & - & & $\boldsymbol{\Delta}$ & $\bullet$ & & & & $\bullet$ & & - & - & - & $\Delta$ & & & & $\Delta$ & - & $\bullet$ & & & $\bullet$ & & - & & - & & & - \\
\hline Sorting and treatment of stone shoulders & & & & & & - & & & $\because$ & - & $\bullet$ & $\bullet$ & - & $\bullet$ & & & - & - & & - & - & & - & $\Delta$ & $\bullet$ & $\bullet$ & - & - & & $\bullet$ & $\bullet$ & & & - & & $\bullet$ & & & - & & & & \\
\hline Injecting wall against moisture & & $\bullet$ & & & & & & & & & & & - & & & & & & - & & & & & & & & & & & & & & - & & & & & & & & & & \\
\hline Wall missing completion & & & & & & & & & & & & & & & & & & & & & & & & & & & & & & & & & & & & & & & & & & & \\
\hline $\begin{array}{l}\text { The processing and restoration of wooden } \\
\text { elements }\end{array}$ & $\Delta$ & - & - & - & $\Delta$ & & & - & - & & & & & & & & & & $\Delta$ & - & - & $\Delta$ & & & & & & - & & $\bullet$ & & $\Delta$ & - & & - & & - & & & & - & & \\
\hline Completing missing wood items & & & & & & & - & & & & & & & & & $\Delta$ & & & & & & & & & & & & & $\Delta$ & & - & & & - & & & & & & & & & \\
\hline Marble restoration & & & & $\Delta$ & - & & & & & & & & & & & - & $\Delta$ & & $\Delta$ & & & & & & & & & & & - & & - & & & - & & & & $\bullet$ & & & & \\
\hline Treating ceilings with moisture effects & & & & & & - & $\Delta$ & & & & $\bullet$ & & & & & & & & & & & & & $\boldsymbol{\Delta}$ & & & & & & & & & & & & & & & & & & & \\
\hline Create a soft ceiling for vulnerable parts & & & & & & & & - & - & $\Delta$ & & - & & & & & & & & & & & - & & & & & & & $\bullet$ & & & & & & & & & & & $\bullet$ & & \\
\hline Roofing for structural security & & & & & & & & $\boldsymbol{\Delta}$ & & & & $\bullet$ & & & - & & & & - & $\bullet$ & - & & & & & $\boldsymbol{\Delta}$ & & & & & & & & - & & $\bullet$ & & - & & & & - & \\
\hline Stairway restoration & & & & & & & & & & - & & & - & & & & & & & & & $\Delta$ & & & & & - & & & & - & & & & & & & & & & & - & - \\
\hline Add paint according to old paint components & & & & & & $\bullet$ & & & & & & $\bullet$ & & & & & & & & $\bullet$ & $\Delta$ & & & & & & & & & & & & & & & & & & $\bullet$ & & & & \\
\hline Restoration and updating of flooring & & - & & & & & $\bullet$ & $\bullet$ & & & & & & & & & & & & & - & - & & $\Delta$ & - & - & - & - & & & - & & & & & & & & & & & - & \\
\hline Update missing slots & & & & & & & & $\boldsymbol{\Delta}$ & & & & & & & - & & & & & & & & & & & & & & & & & & & & & & & & & - & & & \\
\hline
\end{tabular}


[1] North wall, Bab An-nasr \& Bab Al-futuh

[2] Ad-Dardiri House

[3] Al-Madrasa Al-Kamiliyya

[4] The Mosque Of Sharaf Ad-din and His Brother

[5] Qa'at Muhib Ad-Din

[6] Amir Mamay As-sify Miq'ad

[7] Sabil Of Muhammad Ali

[8] Khan Az-Zarakisha

[9] Waqf Al-Mulla House

[10] The Madrasa Of Al-Qadi Abd Al-Basit

[11] the Madrasa Of Az-Zahir Barquq

[12] Ibn Taghri Bardi Mousque

[13] The Madrasa Of Al-Ashraf Barsbay

[14] Qasr al-Amir Bashtak

[15] The Madrasa Of Al-Qadi Yahya Zain Ad-Din Ayoub
[31] The Mosque Of Muhib Ad-Din Abu At-Tayeb

[32] Murad Pasha Mosque

[33] The Zawiya Of Abd Al-Latif Al-Qarafi

[34] The Mosque Of Ali Al-Mutahhar

[19] Abu Ad-Dahab's Tekkia

[35] Sabil and Kutab Of Khusru Pasha Bey Ad-Dahab

[21] Kafour Az-Zimam Mousque

[22] The Mausoleum Of As-Salih Nijm Ad-Din

[36] Wikala, Sabil and Kutab Of Jamal Ad-Din Ad-Dahabi

[37] Hammam Inal

[38] Sabil and Kutab Of Taha Hussain Al-Wardani

[39] Sabil and Kutab Of Kusa Sinan

[40] Sabil Isma'il Al-Maghlawi

[41] Sabil and Kutab Of Amin Iffendi Haiza'

[42] Sabil and Kutab Of Zayn Al-Abidin

[43] Sabil and Kutab Of Al-Kharbutli

[29] Lady Wasila's House

[30] Al-Jawhari Mosque

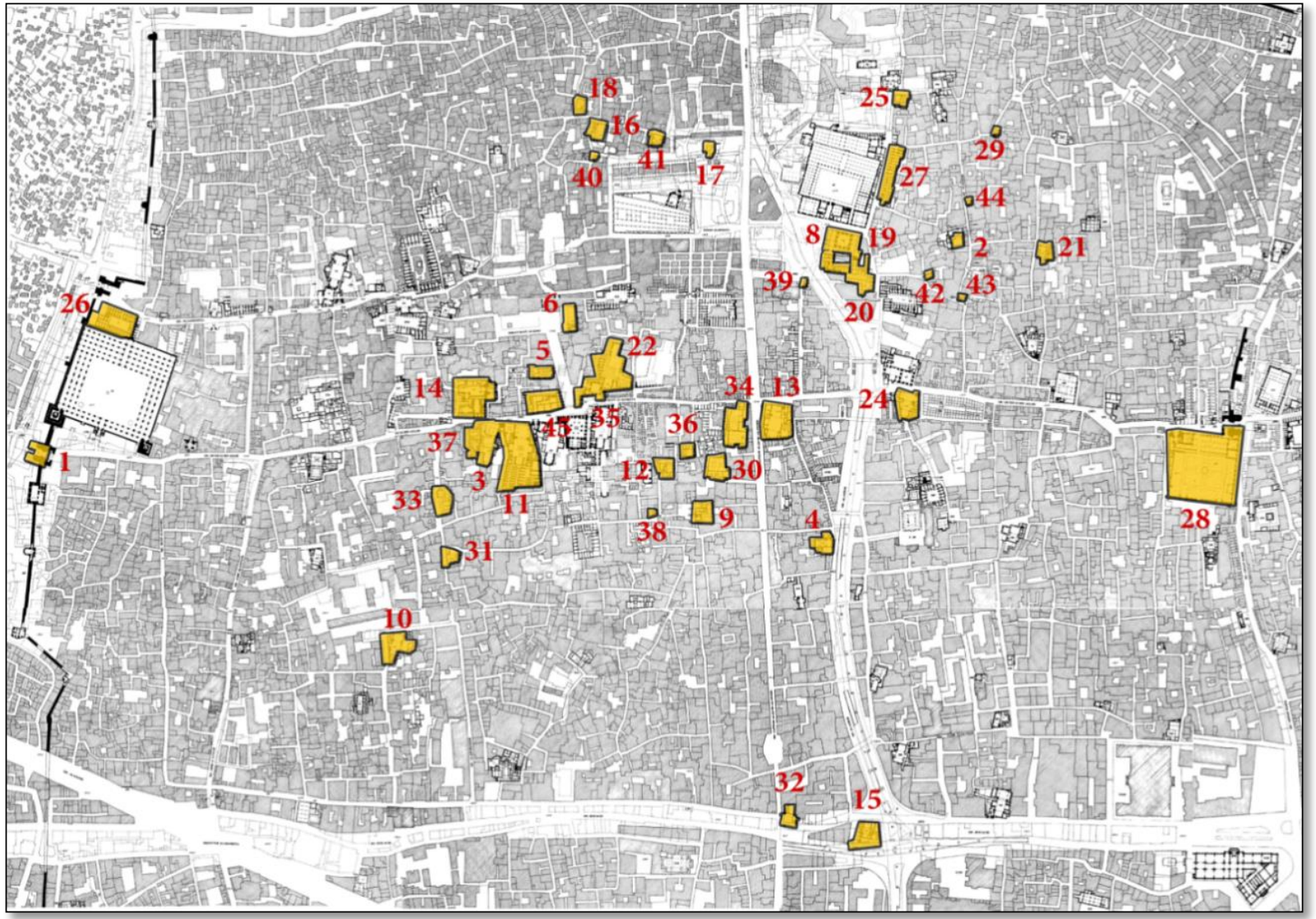

Figure 9. The Case Studies of the historic Cairo Project [58].

According to questionnaire respondents, the following materials were discarded as a result of the historic Cairo conservation project's completion: wood, stone, marble, all types of ceilings, vertical units, floorings, and opening elements. According to respondents, "stone" is the most sustainable heritage building material and has the highest share of reusing its waste, whether in the same project or other projects, followed by wood. The rates of material waste reuse during conservation work are higher than the rates of recycling. Respondents rated reuse, recycling, and 
disposal of waste building materials during various conservation works with the most commonly used building materials, namely stones, wood, and marble (see Figure 10).

A predictive analysis (binary logistic regression) using SPSS (Statistical Package for the Social Sciences) was applied to determine the chances of increasing the efficiency of the current practices used for managing building restoration waste in historic Cairo. Insignificant elements ( $p$-value more than 5\%) were excluded. All the significant elements (in bold and italics, see Table 2), were then arranged according to their expected values. This helped to prioritize building material waste management system elements and accordingly minimized wasted effort and time, leading to a more sustainable waste management system, as shown in table 2 .

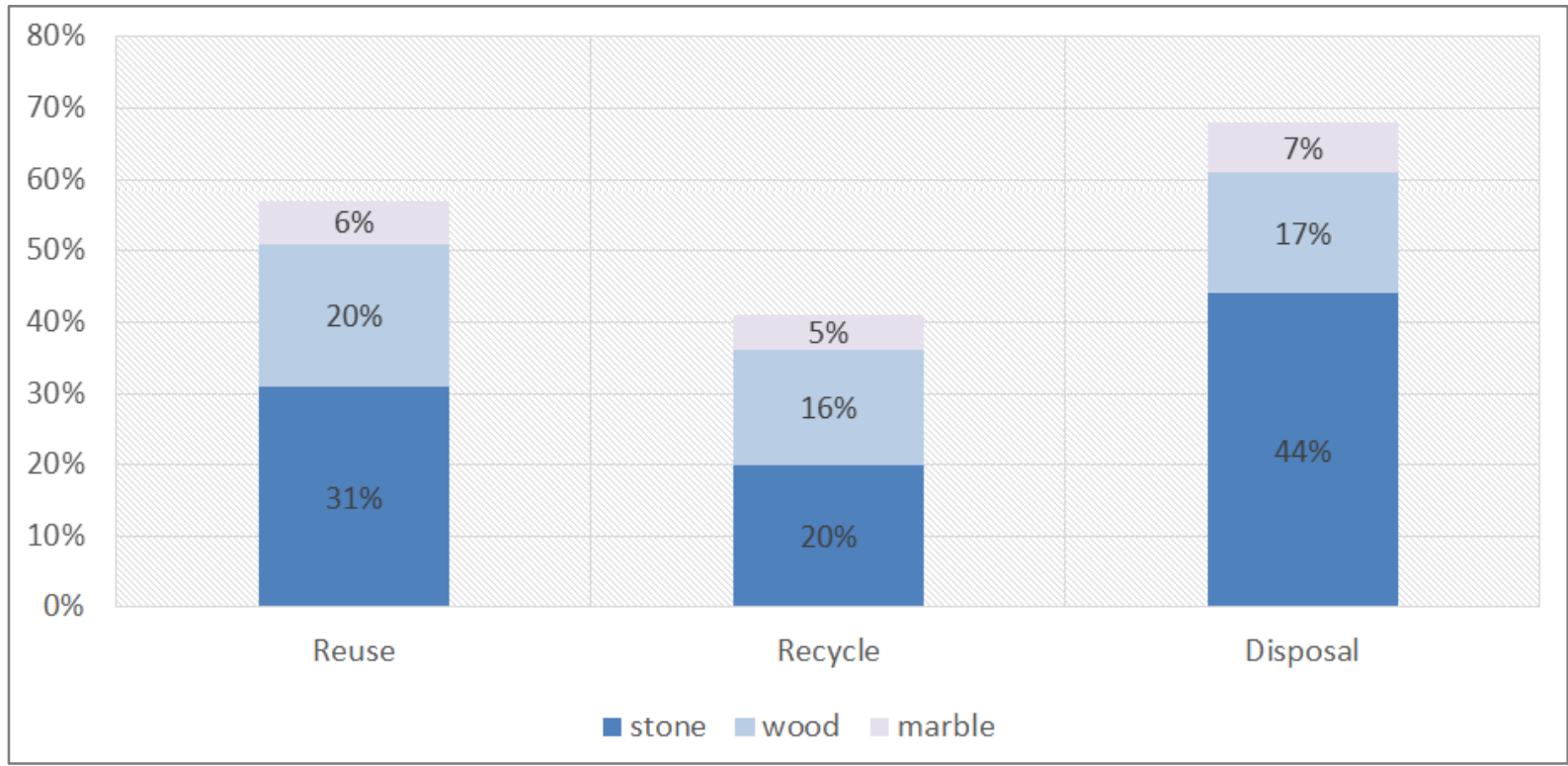

Figure 10. Percentages of material waste management practices for the most used building materials with selected case studies of the historic Cairo project.

Table 2. Results of prioritizing building material waste management system elements (developed by the authors)

\begin{tabular}{|c|c|c|c|}
\hline \multicolumn{2}{|r|}{ Building material waste management system assessment elements. } & P-value & Expected \\
\hline \multirow{5}{*}{ 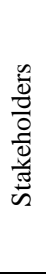 } & Existence of a clear and agreed plan for the waste management of construction materials at the site. & 0.0015 & 3.5322 \\
\hline & Responsibility for managing site construction waste. & 0.6728 & 0.0198 \\
\hline & Commit to international conservation charters and the requirements of heritage site management. & 0.0002 & 0.7373 \\
\hline & Tracking the amount of building materials' waste is tracked through periodic reports. & 0.0001 & 1.2436 \\
\hline & $\begin{array}{l}\text { Coordination between project administrators to reduce the amount of construction waste that } \\
\text { requires final disposal. }\end{array}$ & 0.0000 & 2.0025 \\
\hline \multirow{9}{*}{ 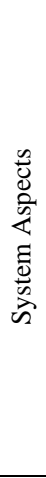 } & Waste sorting up-to-date at each stage of the project. & 0.0001 & 2.8182 \\
\hline & The presence of a designated area for sorting within the site. & 0.0034 & 4.1825 \\
\hline & Manual sorting. & 0.1452 & 0.8135 \\
\hline & Semi-manual sorting. & 0.7049 & 0.1121 \\
\hline & Employing trained workers to sort and reuse. & 0.0000 & 1.0000 \\
\hline & Sorting building material waste to be used later in other projects. & 0.1125 & 0.9682 \\
\hline & Providing clear guidance for reuse or recycling building material waste at the same site or other site. & 0.0545 & 1.3438 \\
\hline & $\begin{array}{l}\text { Availability of markets/places for sale of waste materials at lower prices to be reused in other } \\
\text { projects. }\end{array}$ & 0.0936 & 1.1822 \\
\hline & Testing recycled materials and matching them to standard specifications before they are used. & 0.4315 & 0.6217 \\
\hline \multirow{4}{*}{ 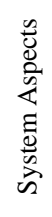 } & Guaranteed safety restrictions before hazardous waste is transported for disposal. & 0.1852 & 0.8901 \\
\hline & Evaluating the environmental impact of new materials and comparing it with recycled materials. & 0.0249 & 4.4244 \\
\hline & Availability of technological capabilities that support the sorting and recycling operations. & 0.0185 & 0.1399 \\
\hline & $\begin{array}{l}\text { The stakeholders caring about public safety rules and providing a good work environment for the } \\
\text { project employees. }\end{array}$ & 0.5193 & 0.1052 \\
\hline
\end{tabular}




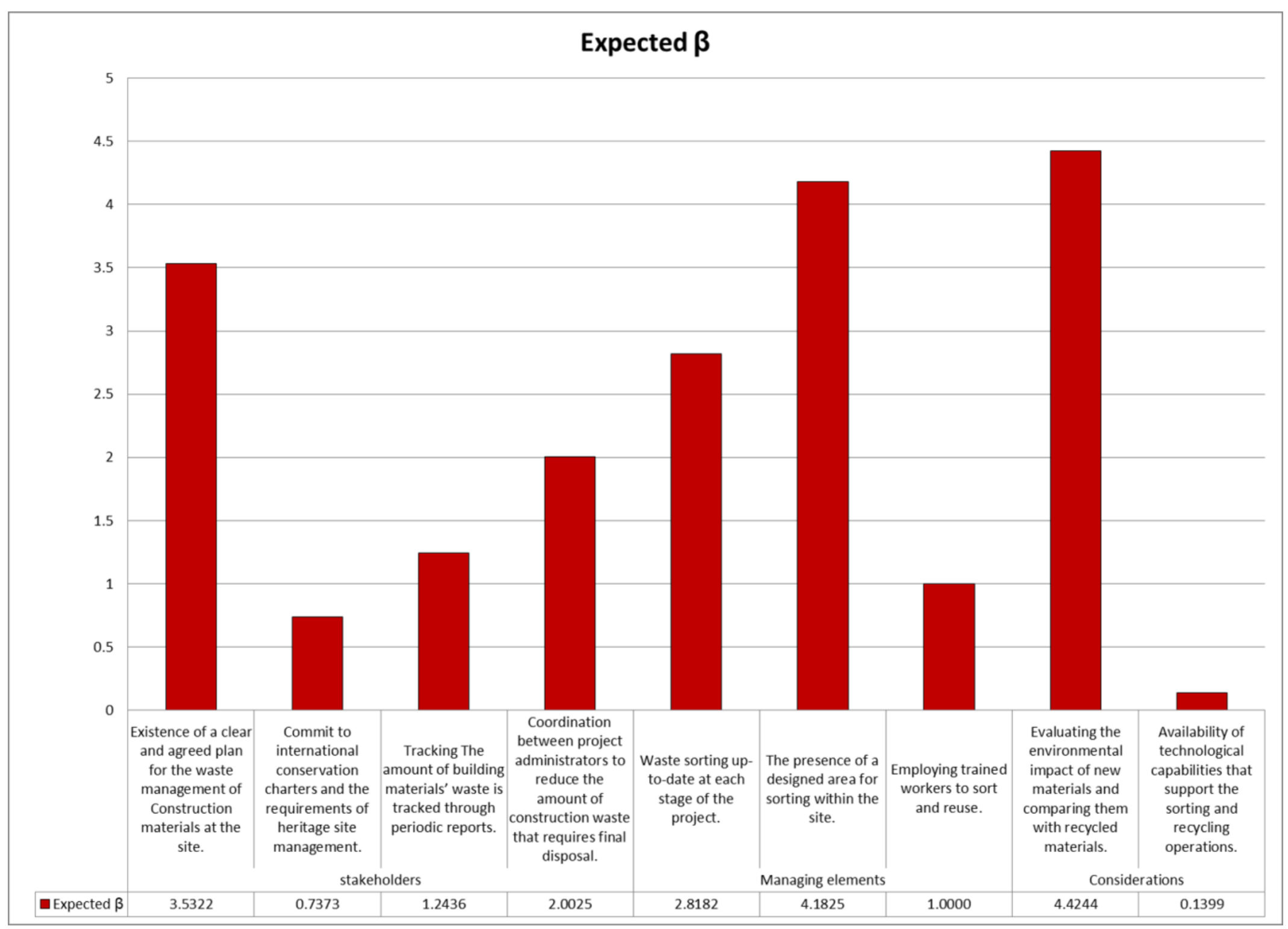

Figure 11. Arrangement of $\beta$ values for significant elements (developed by the authors) 
Data analysis showed that the most important elements of building material waste management systems in historic Cairo are:

- Evaluating the environmental impact of new materials and comparing them with recycled materials to minimize the negative impacts on human health and the environment, and to achieve the maximum degree of genuinely according to the Nara document.

- The presence of a designated area for sorting building materials within the site; because historic sites are located within the urban cluster far from public landfills. This helps to save the materials' value and richness, and decreases the probability of waste dumping in open areas and along road sides.

- Existence of a clear and agreed plan for the waste management of building materials at the site; so as not to be subject to individual decisions.

\section{Building Restoration Waste Management Framework}

Based on the results of the literature review and data analysis gleaned from the survey questionnaire, the research proposed a framework to facilitate the management of building restoration waste in historic Cairo.

\subsection{Definition and Background}

A framework is defined as a structure for describing a set of notions, methods, and tools in a planned outline to complete a product, process, and design [59]. The Building Restoration Waste Management Framework (hereinafter referred to as "the framework" or "BRWMF") is a proposed framework developed by this research to manage building restoration waste in historic Cairo.

\subsection{Need for the Framework}

The proposed framework is needed to provide more structured and highly sustainable management procedures to address deficiencies in current waste management practices, particularly in relation to historic buildings. It is also necessary to maintain the sustainability of historic buildings and manage the waste generated by the historic Cairo restoration process, as well as to save time and effort.

\subsection{Development of the Framework}

The development of the framework was based on the results of the literature review and data analysis gleaned from the survey questionnaire. The literature review showed the increasing global attention being paid to conserving historic buildings due to the significant economic, cultural, and social benefits they provide to communities. In addition, the restoration process for historic buildings is a source of waste which needs to be managed. However, waste management systems encounter a number of deficiencies such as poor coordination, lack of real involvement of stakeholders, lack of perceiving the system components, and affecting the number of external factors. Currently, sustainable waste management systems have been developed to better manage generated waste. Results of the survey questionnaire highlighted the most common practices and materials used for managing waste from historic buildings' restoration. In addition, data analysis showed the most significant building material waste management system elements (see Figure 12).

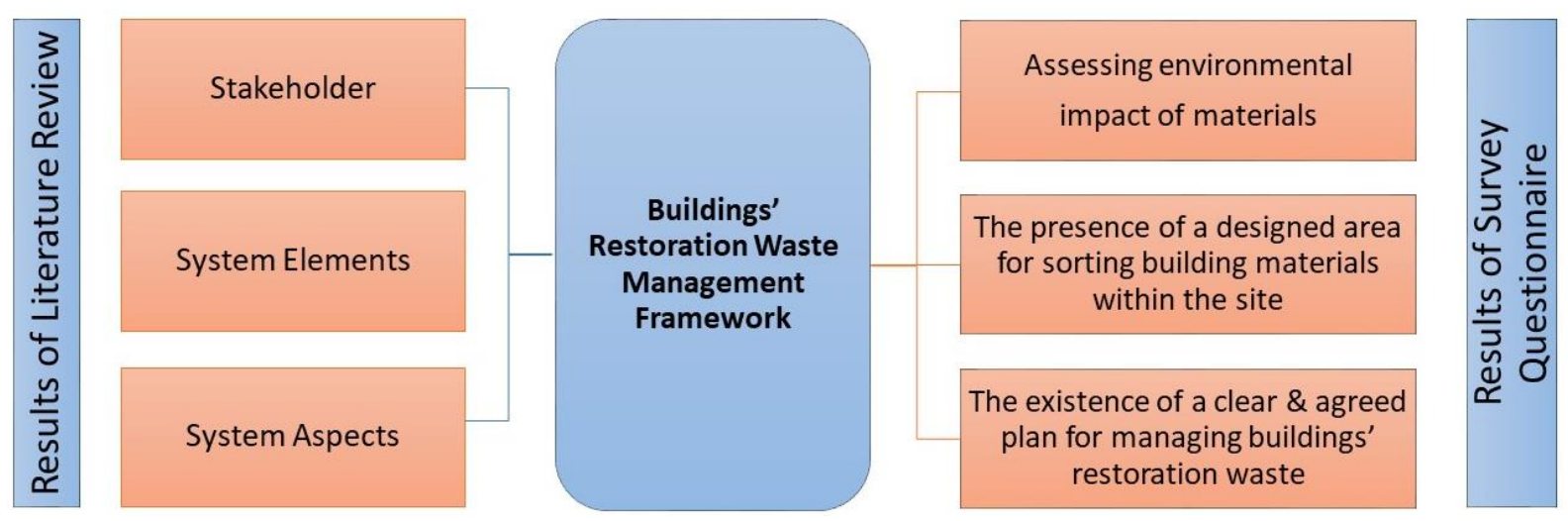

Figure 12. The proposed Building Restoration Waste Management Framework (developed by the authors) 


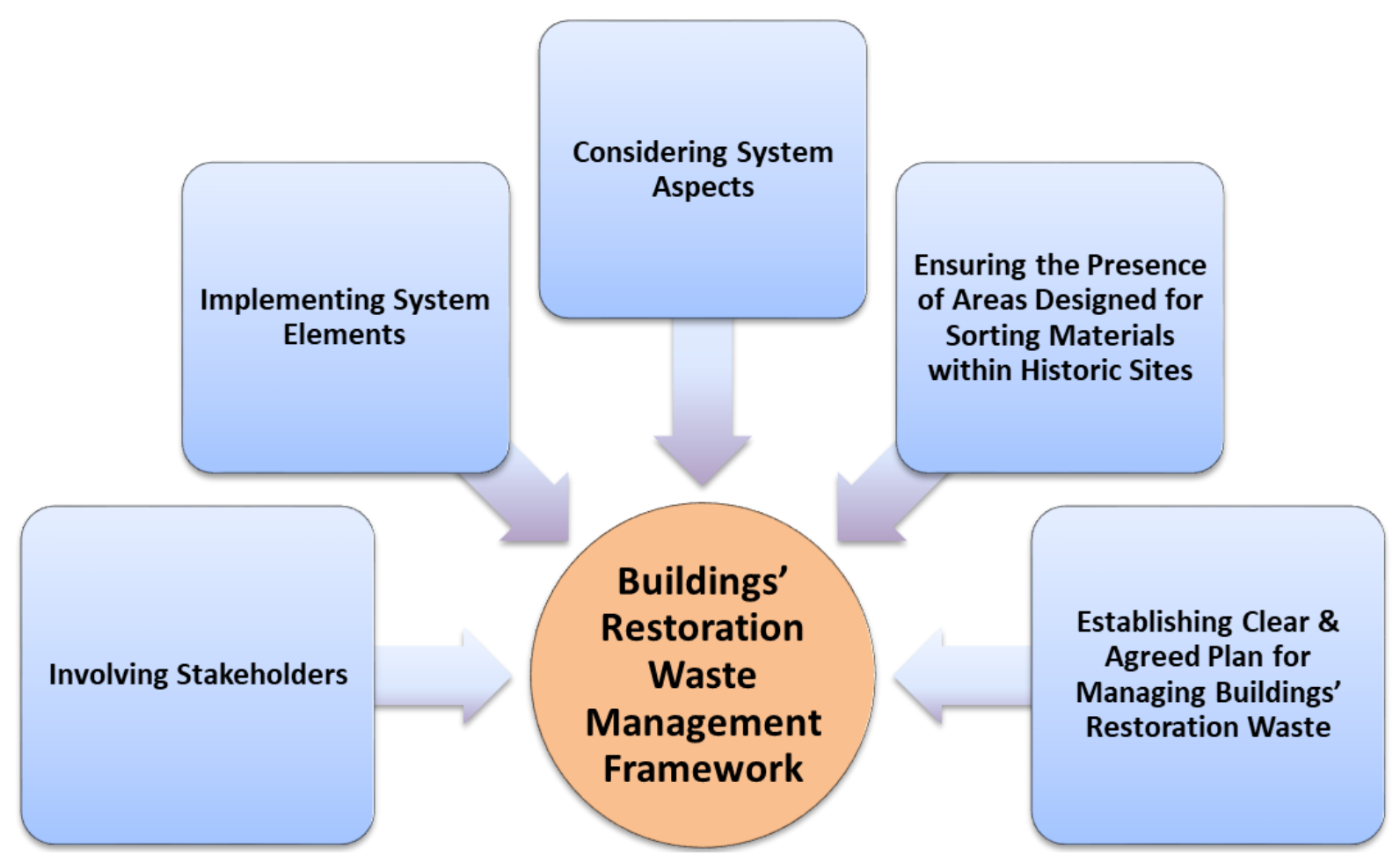

Figure 13. Functions of the Proposed Building Restoration Waste Management Framework (Developed by the Authors)

\subsection{Aim and Description of the Framework}

The BRWMF is a conceptual business improvement tool designed to manage wastes resulting from the restoration of historic Cairo. The framework consists of five functions:

- Involving stakeholders

- Implementing system elements.

- Considering system aspects.

- Ensuring the presence of areas designated for sorting materials within historic sites.

- Establishing a clear and agreed plan for managing building restoration waste (see Figure 13).

\subsubsection{Involving Stakeholders}

The first function of the proposed framework concerns stakeholders' involvement. A stakeholder is a person or organization that has an interest in a certain subject, which is, in our case, managing restoration waste in historic Cairo. Key stakeholders may include local authorities, NGOs, service users, private informal sectors, private formal sectors, and donor agencies. Stakeholders differ from one country, city, or project to another. Thus, they need to be identified in the local context and also grouped according to their interests. Stakeholders by definition have different roles and interests concerning waste management. Stakeholders' involvement helps to get them to agree to co-operate for the common purpose of managing restoration waste. In addition, the stakeholders in a particular city or region share a common social and geographic context and may be bound together by other systems in addition to waste management. The stakeholders' involvement plays a significant role in sharing a common understanding and engagement in the decision-making process related to historic buildings' restoration waste, and leads to empowerment and to joint ownership of the project. To increase their involvement, the restoration project should start with a consultation process that moves to negotiations and ends with joint decisions. The stakeholders' involvement has many benefits such as:

- Ensuring that the project plans are a reflection of the real needs and priorities.

- Allowing the voices of stakeholders to be heard and their issues to be known.

- Promoting transparency in the actions of the project and ensuring that the project is held accountable for its actions.

- Increasing stakeholders' ownership by taking into account their views and motivating them to sponsor the project, this ultimately leads to sustainability.

- Winning project support and gaining commitment to the project, and ultimately increasing the chances for sustainability after the project has been completed.

- Involving the community to which it belongs, and ensuring adherence to international conservation charters and the requirements of heritage site management.

\subsubsection{Implementing System Elements}

The second function of the proposed framework concerns implementing the waste system elements. They 
are referred to as the technical components of waste management systems. The implementation process requires employing trained workers to conduct several waste management activities including separation, collection, transfer \& transport, treatment \& disposal, reduction, reuse, recycling, and recovery.

\subsubsection{Considering System Aspects}

The third function of the proposed framework concerns the consideration of system aspects. Some aspects have to be considered to evaluate the impact of using recycled materials instead of new materials. These aspects are environmental, economic, and technical. This means that, if the recycled material is compared to a newly produced one, the first judgment will be that the recycled material is more sustainable and less harmful to the environment. In addition, the performance of methods of dealing with waste has to be evaluated economically by calculating the costs of energy consumption of machines, tools, and transportation, and studying market prices for both recycled and newly produced materials to compare the cost of manufacturing and transportation and the return from them. Moreover, the necessary technical requirements should be provided by which the recycled materials from the waste resulting from construction and demolition processes can have an efficiency equal to the new materials in their specifications, or less than if they can be accepted by the consumer and the available market.

\subsubsection{Ensuring the Presence of a Designated Area for Sorting Materials within Historic Sites}

The fifth function of the proposed framework concerns offering a place within the historic sites designed and equipped with tools and techniques to enable trained workers to collect, separate and sort reusable waste. This will help to reduce the cost and effort of transferring and transporting reusable waste to a place equipped to receive and collect it near the site, and will ensure that every material is transported to its appropriate recycling facility.

\subsubsection{Establishing a Clear and Agreed Plan for Managing Buildings' Restoration Waste}

The final function of the proposed framework concerns the establishment of clear and agreed on plans for managing building restoration waste. Having an agreed plan will organize the work inside the historic sites and provide ownership of the objectives to be achieved. Moreover, this will help to document the efforts devoted during the restoration and waste management process and ensure the authenticity and originality, and enable the quantities of waste generated and reused later, in the same project or others, to be tracked through periodic reports. 5.5 Framework Benefits and Limitations

The developed framework will impact positively on saving these unique non-renewable resources and preserving their values. In addition, the benefits of the framework lie in its ability to provide solutions to the deficiencies in the current waste management practices and provide organized procedures to facilitate the preservation process. Moreover, the framework will enhance the sustainability of historic sites. On the other hand, the framework's success depends on the encouragement of stakeholders to facilitate the implementation process. The application of the framework is a time-consuming process that requires full dedication from the participants. Due to the nature of the construction industry and the time constraints of restoration projects, this framework may not be welcomed and there may be reluctance in its adoption. The absence of governmental legislation also hinders the implementation of the framework. The framework is designed to address the Egyptian context and its application in other countries may need adaptation to suit their context.

\section{Conclusion and Recommendations}

Historic buildings represent a fundamental part of every country's heritage wealth. Despite the territory on which they are located, historic buildings belong to all people worldwide. Many of these buildings are still standing in a stable state, while others suffer from being ignored and obsolete. Cairo possesses a rich heritage and culture expressed by various architectural and urban elements, and which includes monuments that have witnessed the creativity of its inhabitants for more than a thousand years, which contributed to the production of its unique personality. However, these historic buildings suffer from poor conditions and illegal occupation. The conservation of historic buildings generates waste which needs to be managed to increase the sustainability of these buildings. Waste management systems fail due to poor coordination, lack of stakeholders' involvement, lack of understanding of the system components, and certain external affecting factors. Several studies have been conducted to enhance the waste management system. As a result, an integrated sustainable waste management system has been developed.

This system is built on three main pillars, namely, stakeholders, waste management elements, and system aspects. The results of a survey questionnaire conducted with a representative sample of experts and project managers in the historic Cairo conservation project showed that "stone" is the most sustainable heritage building material and has the highest share of reuse, whether in the same project or in other projects, followed by wood. Data analysis showed that the most important elements of building material waste management systems in historic Cairo include the evaluation of the environmental impact of new materials and comparing them with recycled materials, the presence of a designated area for sorting building materials within the site and the 
existence of a clear and agreed plan for the waste management of building materials at the site. Based on the above, the research developed a framework consisting of five functions to manage building restoration waste in historic Cairo. At this point, the research comes with the following recommendations:

- Increasing awareness in the community about the value of heritage buildings and the need to preserve and maintain these buildings.

- Establishing clear legislations and unified principles for resource management that include collection, separation, transportation, and disposal practices that are implemented with the participation of stakeholders, while reinforcing the trend toward reducing restoration waste of historic buildings.

- Apply the proposed framework on a wider sample of different types of buildings to estimate their priorities for the waste management plan.

- Investigating legal aspects of waste management at historic sites in preserving environmental laws; especially historic sites that are attached to residential places.

- Providing enough containers to contain the site's waste, in which each of them has an appropriate cover, and is compatible in shape, size, and design with public health requirements, and separate from the organic waste.

- Providing spaces within historic sites for sorting restoration materials, thus avoiding the cost and effort of transporting these materials.

- Supporting communications between stakeholders for better decisions related to the management of waste from historic building restoration.

- Encouraging the reuse practices as they are the most sustainable and consume the least energy, while storing material waste to be easily reused in other projects in the future or in renovation works on the same site, and allocating places for it.

- Adopting the developed framework as an approach for managing building restoration waste to suit the context of historic sites; to be evaluated and to improve its performance.

\section{Disclosure Statement}

No potential conflict of interest was reported by the author.

\section{REFERENCES}

[1] Bullen P.A., P.E. Love, "The rhetoric of adaptive reuse or reality of demolition: Views from the field". Cities. Vol.27, no.4, pp.215-24, 2010. https://doi.org/10.1016/j.cities.2009 .12 .005 .
[2] Department of Environment and Heritage (DEH), Adaptive Reuse. Commonwealth of Australia, Canberra, 2004. https://www.environment.gov.au/system/files/resources/38 45f27a-ad2c-4d40-8827-18c643c7adcd/files/adaptive-reus e.pdf.

[3] Ball R., "Developers, regeneration and sustainability issues in the reuse of vacant industrial buildings". Building Research \& Information. Vol.27, No.3, pp.140-8, 1999. DOI: $10.1080 / 096132199369480$.

[4] Reed R.G., Wilkinson S.J., "The business case for incorporating sustainability in office buildings: The adaptive reuse of existing buildings". In: Proceedings of 14th Annual Pacific Rim Real Estate Society Conference, Pacific Rim Real Estate Society, Kuala Lumpur, 2008 Jan, (pp. 1-18). https://dro.deakin.edu.au/view/DU:30019171.

[5] Wilkinson S.J., James K. and Reed R., "Using building adaptation to deliver sustainability in Australia", Structural Survey, Vol.27, No.1, pp.46-61, 2009. https://doi.org/10.1108/02630800910941683.

[6] Udawatta N., Zuo J., Chiveralls K., G. Zillante, “Attitudinal and behavioural approaches to improving waste management on construction projects in Australia: benefits and limitations". International journal of construction management, Vol.15, No.2, pp.137-47, 2015. https://doi.org/10.1080/15623599.2015.1033815.

[7] T. Santhosh Kumar, Balaji K.V.G.D, Ch. Sandeep Reddy, K. Chitti Babu, Ch. Lakshmi Sowjanya, "Performance of $\mathrm{CO} 2$ Cured Sugar Cane Bagasse Ash Concrete in Marine Environment," Civil Engineering and Architecture, Vol.8, No.5, pp.771-776, 2020. DOI: 10.13189/cea.2020.080504.

[8] Li M., "A waste management system for small and medium enterprises engaged in office building retrofit projects." $\mathrm{PhD}$ diss., Queensland University of Technology, 2012.

[9] Marshall R. E., \& Farahbakhsh, K., "Systems approaches to integrated solid waste management in developing countries". Waste management, Vol.33, No.4, pp.988-1003, 2013. https://doi.org/10.1016/j.wasman.2012.12.023.

[10] Antiquities and Monuments Office, Leisure and Cultural Services Department. "Assessment of 1,444 Historic Buildings". Available at http://www.amo.gov.hk/en/ built2.php. accessed at 2021January 23 .

[11] Damla Misırlısoy, "Rethinking Municipal Markets (Bandabuliya) within the Context of Sustainability: Case of Cyprus," Civil Engineering and Architecture, Vol.9, No.3, pp.883 - 891, 2021. DOI: 10.13189/cea.2021.090330.

[12] Hegazi Y.S., Shalaby H.A., M.A.A. Mohamed, “Adaptive Reuse Decisions for Historic Buildings in Relation to Energy Efficiency and Thermal Comfort-Cairo Citadel, a Case Study from Egypt". Sustainability, Vol.13, No.19, pp:10531, 2021. https://doi.org/10.3390/su131910531.

[13] Bose S., "Restoration of Town Hall in Kolkata for adaptive reuse: a case study", Structural Survey, Vol.30, No.3, pp. 280-291, 2012.https://doi.org/10.1108/0263080121124 1838.

[14] Othman A.A., Heba E., “Adaptive reuse: an innovative approach for generating sustainable values for historic buildings in developing countries". Organization, technology \& management in construction: an international 
journal, Vol.10, No.1, pp.1704-18, 2018.

[15] Hegazy, S.M., "Conservation of historical buildings-The Omani-French museum as a case study". HBRC Journal, vol.11, no.2, pp.264-274, 2015. https://doi.org/10.1016/j.h brcj.2014.03.010.

[16] Studio Persevoir, "Omani French Museum (patio)", http://canvas.pantone.com/gallery/47647887/Omani-Frenc h-Museum-(patio). Retrieved at 2020 December 17.

[17] David I., "The best museums to see in Muscat". https://theculturetrip.com/middle-east/oman/articles/thebes t-museums-to-see-in-muscat/. Retrieved at 2020 December 17.

[18] UNESCO, WCH., "Urban regeneration project for historic Cairo." Cairo: Capmas, 2012. https://whc.unesco.org/docu ment/120189.

[19] Hegazi Y. S., "Cultural World Heritage Lists Nominations Management and Monitoring", $\mathrm{PhD}$ diss, Cairo university, 2011.

[20] Ministry of antiquities, "Glory of Islamic Architecture: A Mission to Preserve Heritage," 2006.

[21] Hegazi Y. S., "Conservation Project Management Thought Development of Islamic Architectural Heritage in Cairo", Master's thesis, Cairo university, 2005.

[22] El-Rayes A. E.-S, International conventions and recommendations for dealing with architectural and architectural heritage", $\mathrm{PhD}$ diss, Cairo university, 2006.

[23] ICOMOS, "The Nara document on authenticity, International council on Monuments and sites", 1994. Online, available from: https://www.icomos.org/charters/n ara-e.pdf .Retrieved at 2021 March 1.

[24] Supreme council of antiquities, "Historic Cairo", 1st ed. Pp.1-440, 2002.

[25] Hawas S. Z., "Urban Conservation. Regeneration of Heritage Areas in Egypt, AgaKhan Darb Al-Ahmar Project Model: Aga Khan Cultural Services”, 2013.

[26] [26] Diaz L., Savage G. \& Golueke C., "Sustainable community systems: the role of integrated solid waste management". International madison waste conference municipal and industrial waste, department of engineering professional development, 1996, pp.280-291.

[27] Sudhir V., Muraleedharan V., G. Srinivasan, "Integrated solid waste management in urban India: a critical operational research framework". Socio-Economic Planning Sciences, Vol.30, No.3, pp.163-181, 1996. https://doi.org/10.1016/0038-0121(96)00012-2.

[28] Wilson D.C., "Development drivers for waste management". Waste Management \& Research, Vol.25, No.3, pp.198-207, 2007.https://doi.org/10.1177/0734242X 07079149 .

[29] Schübeler P., Christen J., K. Wehrle, "Conceptual framework for municipal solid waste management in low-income countries", Vol.9, St. Gallen, SKAT (Swiss Center for Development Cooperation), 1996.

[30] Anschütz J., Ijgosse J., A. Scheinberg, "Putting integrated sustainable waste management into practice". Waste
Netherland, 1st ed., pp.1-102, 2004.

[31] Chung S.-S., Lo C.W., "Evaluating sustainability in waste management: the case of construction and demolition, chemical and clinical wastes in Hong Kong". Resources, conservation and recycling, Vol.37, No.2, pp.119-145, 2003. https://doi.org/10.1016/S0921-3449(02)00075-7.

[32] Klang A., Vikman P.-Å., H. Brattebø, "Sustainable management of demolition waste - an integrated model for the evaluation of environmental, economic and social aspects". Resources, Conservation and Recycling, Vol.38, No.4, pp.317-334, 2003. https://doi.org/10.1016/S0921-34 49(02)00167-2.

[33] Yuan H., Wu H., J. Zuo, “Understanding factors influencing project managers' behavioral intentions to reduce waste in construction projects". Journal of Management in Engineering, Vol.34, No.6, 2018.

[34] Nagapan S., Rahman I. A., Asmi A., Memon A. H., Latif I., "Issues on construction waste: The need for sustainable waste management". 2012 IEEE colloquium on Humanities, Science and Engineering (CHUSER), 2012, December, pp. 325-330.

[35] Nag A. "Environmental education and solid waste management", New Age International, 2005.

[36] Hoffmann Sampaio C., Ambrós W.M., Cazacliu B.G., Oliva Moncunill J., Veras M.M., Miltzarek G.L., Silva L.F.O., Kuerten A.S., Liendo M.A., "Construction and Demolition Waste Recycling through Conventional Jig, Air Jig, and Sensor-Based Sorting: A Comparison.", Minerals, Vol.11, No.8, pp.904, 2021. https://doi.org/10.3390/min11 080904).

[37] Johnston H., Mincks W.R., "Cost-effective waste minimization for construction managers", Cost Engineering, Vol.37, No.1, pp.31, 1995.

[38] Shen L. Y., Tam V. W., Tam C. M., Drew D., "Mapping approach for examining waste management on construction sites". Journal of construction engineering and management, Vol.130, No.4, pp.472-481, 2004. DOI: 10.1061/(ASCE)0733-9364(2004)130:4(472).

[39] Wang J., Yuan H., Kang X., Lu W., "Critical success factors for on-site sorting of construction waste: a China study", Resources, conservation and recycling, Vol.54, No.11, pp.931-936, 2010.

[40] Goverse T., Hekkert M. P., Groenewegen P., Worrell E., Smits R. E., "Wood innovation in the residential construction sector; opportunities and constraints. Resources", Conservation and Recycling, Vol.34, No.1, pp.53-74, 2001. https://doi.org/10.1016/S0921-3449(01)00 093-3.

[41] Kabirifar K., Mojtahedi M., Wang C., Tam V. W., "Construction and demolition waste management contributing factors coupled with reduce, reuse, and recycle strategies for effective waste management: A review". Journal of Cleaner Production, Vol.263, pp.121265, 2020. https://doi.org/10.1016/j.jclepro.2020.121265.

[42] Huang B., Wang X., Kua H., Geng Y., Bleischwitz R., Ren J., "Construction and demolition waste management in China through the 3R principle". Resources, Conservation and Recycling, Vol.129, pp.36-44, 2018. 
https://doi.org/10.1016/j.resconrec.2017.09.029.

[43] Mulders L., "High quality recycling of construction and demolition waste in the Netherlands", Master's thesis, Utrecht university, faculty of geosciences, sustainable development - energy and resources, 2013.

[44] Yeheyis M., Hewage K., Alam M. S., Eskicioglu C., Sadiq R., "An overview of construction and demolition waste management in Canada: a lifecycle analysis approach to sustainability" Clean technologies and environmental policy, Vol.15, No.1, pp.81-91, 2013. DOI. 10.1007/s10098-012-0481-6.

[45] Peng C.-L., Scorpio D.E., Kibert C.J., "Strategies for successful construction and demolition waste recycling operations", Construction Management \& Economics, Vol.15, No.1, pp.49-58, 1997.https://doi.org/10.1080/0144 61997373105.

[46] Ponnada M. R., Kameswari P., "Construction and demolition waste management-A review", safety, Vol.84, pp.19-46, 2015. http://dx.doi.org/10.14257/ijast.2015.84.0 3.

[47] Van Den Berg M., Voordijk H., Adriaanse A., "Recovering building elements for reuse (or not) - Ethnographic insights into selective demolition practices", Journal of Cleaner Production, Vol.256, pp.120332, 2020. https://doi.org/10.1 016/j.jclepro.2020.120332.

[48] Mcdonough W., Braungart M., "Cradle to cradle: Remaking the way we make things", North point press, 2010.

[49] Tchobanoglous G., Kreith F., "Handbook of solid waste management", McGraw-Hill Education, New York, 2nd ed., 2002.

[50] Moraes F.T.F., Gonçalves A.T.T., Lima J.P., Lima, R.D.S., "An assessment tool for municipal construction waste management in Brazilian municipalities". Waste Management \& Research, Vol.38, No.7, pp.762-772,
(2020). https://doi.org/10.1177/0734242X20906886.

[51] Kofoworola O.F., Gheewala S.H.,"Estimation of construction waste generation and management in Thailand". Waste Management, Vol.29, No.2, pp.731-738, 2009. https://doi.org/10.1016/j.wasman.2008.07.004.

[52] Stenis J., "Construction waste management based on industrial management models: a Swedish case study", Waste management \& research, Vol.23, No.1, pp.13-19, 2005. https://doi.org/10.1177/0734242X05050184.

[53] Wu H., Zuo J., Yuan H., Zillante G., Wang J., “A review of performance assessment methods for construction and demolition waste management", Resources, Conservation and Recycling, Vol.150, pp.104407, 2019. https://doi.org/10.1016/j.resconrec.2019.104407.

[54] Mrayyan B., Hamdi M.R., "Management approaches to integrated solid waste in industrialized zones in Jordan: A case of Zarqa City", Waste Management, Vol.26, No.2, pp.195-205, 2006. https://doi.org/10.1016/j.wasman.2005. 06.008 .

[55] Cohen L., Manion L., Morrison K., "Research methods in education”, routledge, 5th ed., 2002.

[56] Groat L.N., Wang D., "Architectural research methods". John Wiley \& Sons, 2nd ed., 2013.

[57] Jenkins D.G., Quintana-Ascencio P.F., "A solution to minimum sample size for regressions", PLoS ONE, Vol.15, No.2, 2020. https://doi.org/10.1371/journal.pone.0229345.

[58] Warner N. "The monuments of historic Cairo: A map and descriptive catalogue". Cairo: American University in Cairo Press, 2005. https://www.academia.edu/3886090/Cai ro_architecture.

[59] Othman E., Ahmed A., "Improving building performance through integrating constructability in the design process". Organization, technology \& management in construction: an international journal, Vol.3, No.2, pp.333-347, 2011. 